\title{
The making of a maritime explorer: the early career of Matthew Flinders
}

\section{Kenneth Morgan*}

\section{Department of Politics, History and Law, Brunel University London}

\section{*Email: kenneth.morgan@brunel.ac.uk}

\begin{abstract}
This paper examines the early career of Matthew Flinders to determine the ways in which his training as a navigator, hydrographer and cartographer prepared him for undertaking the first circumnavigation of Australia in HMS Investigator between 1801 and 1803. Two main questions are answered in relation to this theme: Why was such a young naval officer as Flinders (he was twenty-six) selected to lead such an important voyage of discovery? And in what ways did the choice of Flinders as the commander of the Investigator reflect the training he had received? The paper argues that the making of Flinders as a maritime explorer was forged through his successive nautical achievements in the 1790s, partly in relation to Bligh's second breadfruit voyage to the Pacific in 1791/2, on which he was trained by Bligh in cartography and hydrography, and partly in relation to the voyages along the southeastern Australian coast and Van Diemen's Land that Flinders undertook between 1795 and 1800 while stationed at Port Jackson. During that period, Flinders jointly discovered Bass Strait and circumnavigated Van Diemen's Land: these were the two most significant geographical discoveries in Australia since the era of Captain Cook. The paper shows that in 1800, when he returned from Port Jackson to London, Flinders was the most experienced candidate with knowledge of Australian waters who was available to lead the Investigator expedition. It also argues that Flinders placed himself in a highly favourable position to be selected as the leader of the circumnavigation through demonstrating to his patron, Sir Joseph Banks, that he had a thorough, up-to-date knowledge of what needed to be discovered about Australia through maritime exploration. Throughout the paper there will be an emphasis on the nautical skills Flinders acquired rapidly as a young midshipman and lieutenant and on his determination and initiative to devote his career to Australian discovery.
\end{abstract}

\section{Keywords}

Exploration; Australia; Navigation; Patronage; Charts 


\section{Text}

This paper examines the early career of Matthew Flinders to determine how his training as a navigator, hydrographer and cartographer prepared him for undertaking the first circumnavigation of Australia. Born in Lincolnshire in 1774, Flinders joined the navy at the age of sixteen. ${ }^{1}$ At the age of twenty-six he was appointed commander of HMS Investigator, which set about the most thorough survey of coastal Australia yet undertaken. At the time, the western half of Australia was known as New Holland (after the Dutch discoveries of the seventeenth century) while the eastern portion was the British colony of New South Wales. As a result of the Investigator's expedition, which occupied two years from mid-1801 to mid1803, Flinders proved that Australia was one landmass, not two as contemporary geographers then thought; he produced a comprehensive set of accurate charts and maps of Terra Australis; he greatly improved hydrographical knowledge of Australian waters; he named hundreds of Australian capes, coves, rivers and islands; and he eventually published a detailed voyage account of his expedition entitled A Voyage to Terra Australis. ${ }^{2}$ Why was a young naval officer such as Flinders selected to lead such an important voyage of discovery? In what ways did the choice of Flinders as the commander of the Investigator reflect the training he had received? This paper answers these questions by looking at the navigational skills acquired by Flinders and his knowledge of sailing in Australian waters before the outset of the Investigator's expedition.

Flinders's desire to become a maritime explorer arose from his own volition in the first instance. As a teenager he read Robinson Crusoe, finding the exotic setting of the novel gave him 'an intense longing for adventure. ${ }^{3}$ By the age of fifteen, on the advice of a cousin who had served in the navy, Flinders had read and studied material on geometry, nautical astronomy, trigonometry and navigation in contemporary books such as John Robertson's 
Elements of Navigation (revised in 1780) and John Hamilton Moore's The Practical Navigator and New Daily Assistant (11 ${ }^{\text {th }}$ edition, 1795). Through family connections Flinders gained the initial patronage necessary for a naval career from Thomas Pasley, a frigate captain who helped Flinders secure junior appointments on several naval vessels in 1789-91. Mainly based at Chatham dockyard, Flinders learned about seamanship and shipboard routines. ${ }^{4}$ These studies, to which he applied himself assiduously, and acquaintance with the practicalities of shipboard life, were foundations for a career in the navy. But it was Pasley's introduction of Flinders to his acquaintance William Bligh for an oceanic voyage that trained Flinders in navigational and cartographic skills that would be used on his circumnavigation of Australia. $^{5}$

In 1791 Flinders set out under Bligh's command in HMS Providence on an expedition intended to transplant breadfruit from Tahiti across the Pacific, Atlantic and Indian oceans to the West Indies, where it was intended to serve as a nutritious foodstuff for plantation slaves. The voyage of the Providence was the fourth undertaken by Bligh in the Pacific and the second whose main focus was to acquire breadfruit. The first breadfruit expedition led by Bligh had fallen apart after the notorious mutiny on the Bounty near Tofoa (now Tonga, South Pacific) where, on 28 April 1789, mutineers had set Bligh adrift on a seven-metre longboat, with eighteen loyal followers. ${ }^{6}$ The second breadfruit voyage attempted to redress this failed mission. Though Bligh had a reputation for imposing strict authoritarian discipline and for unsettling verbal outbursts on board ship, he had significant connections and navigational experience that were vital for Flinders' ambitions.

On both breadfruit voyages, Bligh received patronage from Sir Joseph Banks, President of the Royal Society, a leading promoter of maritime exploration and an expert on imperial botany. ${ }^{7}$ In 1770 Banks had sailed with James Cook in the Endeavour, and had left a detailed account of his visit to Botany Bay and Australia's east coast. Cook was the first European navigator to survey much of southeastern and eastern Australia from the coastal headland of Point Hicks (now in Victoria) up to the top of the Cape York peninsula. ${ }^{8}$ Bligh had sailed as a master on Cook's third voyage of Pacific exploration in the Resolution between 1776 and 1780. During that voyage he visited Tahiti and learned important navigational and cartographic skills from Cook. ${ }^{9}$ On his first breadfruit expedition, after being cast adrift in the Bounty's launch, Bligh's superior navigational skills had steered his small open boat over 3,168 nautical miles safely into Timor after forty-seven days at sea, a remarkable feat of navigation through treacherous waters. ${ }^{10}$

During the breadfruit voyage in the Providence, Flinders picked up essential nautical information and skills from Cook's influence and from Bligh. He had a copy to hand of John Hawkesworth's official account of Cook's first Pacific voyage, published in 1773. Flinders kept a logbook on board the Providence in which he commented on the ship's provisions for a long oceanic voyage, listing what was issued to the crew on a daily basis. The details are mainly copied verbatim from Cook 'whose attention in preserving the Health of his Men was unremitted. ${ }^{11}$ Flinders's commentary in his logbook on the dances and gestures of the Tahitians shows that he had read Cook's description of these people. ${ }^{12}$ 
The Providence sailed along the south coast of New Guinea, reaching Possession Island in Torres Strait, off the northern end of the Cape York peninsula, in September 1792. Flinders would have known this was where Cook had landed from the Endeavour on 22 August 1770, and had claimed the land he had just sailed by, which he called New South Wales, for Britain. ${ }^{13}$ Though Flinders did not write extensively about Cook's influence on him as a navigator either on this breadfruit voyage or before his Australian circumnavigation, he later wrote explicitly about Cook's achievements as an explorer, paying handsome tribute to the capabilities of a master mariner whose charts and written works he held 'sacred.' Flinders considered himself to be 'in some sort' Cook's 'disciple.' ${ }^{\text {, }}$

After his circumnavigation of Australia, Flinders acknowledged he had made his 'first acquirements in nautical science...under one [Bligh] who mostly gained his from that great master [Cook] himself.' ${ }^{15}$ Flinders' log and journal in the Providence indicates that he had acquired a sound knowledge of calculating latitude and longitude, of making astronomical observations by dead reckoning, and of variations associated with compasses. He had a good knowledge of chronometers partly because Bligh allowed his midshipmen to oversee their operation. This familiarised Flinders with the use of these precision clocks that he later used on his Australian circumnavigation. Flinders also took lessons from Bligh on chart construction. ${ }^{16}$ Bligh had a high reputation for the precision of his charts and for the accuracy with which he conducted running surveys, skills he had learned while sailing with Cook. ${ }^{17}$

Flinders drew at least seven plans and one chart while on the voyage, but it is unlikely that he compiled any of the official large charts. ${ }^{18}$ Bligh allocated the task of charting Adventure Bay, on an island off Van Diemen's Land, to Flinders. ${ }^{19}$ Sketches of the track of the voyage of the Providence and its tender the Assistant inserted at the beginning of Flinders's logbook reveal an increasing confidence in drawing maps and charting the course followed. ${ }^{20}$ Flinders drew one chart - of Torres Strait. It was entitled A Chart of the Passage between New Holland and New Guinea as seen in His Majesty's ship Providence in 1792. This was intended to accompany his log. He signed the chart 'M. Flinders.' 21 This was Flinders’s first-known nautical chart. It was probably prepared under Bligh’s supervision. ${ }^{22}$

During the voyage in the Providence, Flinders also learned much from Bligh's skill in navigating a vessel in difficult conditions. After leaving Tahiti on 19 July 1792, and proceeding towards the East Indies, Bligh steered the Providence safely through the dangerous waters of Torres Strait, sailing through a passage he named 'Bligh's Entrance.' He had traversed this route before in the Bounty and the Bounty's launch. Bligh compiled a careful running survey of those seas to which Flinders had recourse on future voyages. The Assistant was attacked by Torres Strait Islanders in canoes on 11 September 1792. The islanders shot arrows and wounded three of the crew, but Bligh countered the attack by ordering two quarterdeck guns to fire grape shot against the attackers. This dispersed the assault. ${ }^{23}$ Flinders later praised Bligh's skill in navigating Torres Strait and its extensive reefs in nineteen days, fighting off the Torres Islanders. ${ }^{24}$ As G. Arnold Wood put it, 'Flinders had the chance of observing under a captain...the greatest difficulties in the way of navigation, and how to overcome them, ${ }^{25}$ Bligh and Flinders clashed over various matters on the breadfruit expedition that were unconnected with nautical expertise; but when Flinders took 
his lieutenant's examination in 1797, Bligh referred to his 'diligence, sobriety and obedience to command. 26

The voyage in the Providence gave Flinders experience in sailing across three oceans, and improved his nautical and charting skills through learning from Bligh and Cook's example. These areas of expertise were vital for the progression of Flinders' naval career, but his suitability for the circumnavigation of Australia in the Investigator was boosted by his experience as a midshipman and lieutenant based at Port Jackson, the base for the British colony of New South Wales, for over five years between 1795 and 1800. Flinders's opportunity to go to Port Jackson arose through a friendship with Henry Waterhouse, with whom he had served in the naval vessel Bellerophon after his return from the breadfruit voyage. By the end of July 1794 Waterhouse had been appointed second captain on the voyage of the Reliance taking out a new governor, John Hunter, to New South Wales. ${ }^{27}$ Flinders joined the Reliance as senior master's mate. ${ }^{28}$ With regard to this expedition, Flinders later noted that he was 'led by his passion for exploring new countries, to embrace the opportunity of going out upon a station, which of all others, presented the most ample field for his favourite pursuit.' ${ }^{29}$ On the voyage out to Port Jackson, Flinders gained further experience of nautical astronomy by using a timekeeper to calculate longitude by celestial navigation and a meridional compass to determine longitude by magnetic variation. ${ }^{30}$

Flinders's activities at Port Jackson gave him ample opportunity to further his knowledge of Australia's coastal waters within reach of Port Jackson. His endeavours were supported by two main allies from the voyage in the Reliance. One was his friend George Bass, a young naval surgeon. Bass was three years older than Flinders; he was widely read and shared Flinders' penchant for geographical discovery. ${ }^{31}$ Flinders was impressed by Bass's determination and ability. 'In Mr George Bass, surgeon of the Reliance,' he later wrote, I had the happiness to find a man whose ardour for discovery was not to be repressed by any obstacles, nor deterred by danger; and with this friend a determination was formed of completing the examination of the east coast of New South Wales, by all such opportunities as the duty of the ship, and procurable means, could admit.' 32

Flinders's other main ally in Port Jackson was the governor of the colony, John Hunter. He was a former naval officer, an experienced maritime surveyor, and keenly interested in the exploration of New South Wales. The hydrographer Geoffrey C. Ingleton claimed that Hunter was 'a more qualified and accomplished hydrographic surveyor than Bligh. ${ }^{33}$ In 1788-9, while serving with the First Fleet of convicts to New South Wales, Hunter had charted Port Jackson, Broken Bay and Botany Bay, all within a twenty-mile radius of the British settlement at Sydney Cove. ${ }^{34}$ What lay beyond these areas was unknown to Europeans. Thus Flinders, who found Hunter receptive to his ideas for further local exploration, later noted that intermediate parts of coastal New South Wales, both to the north and south of Port Jackson, 'were little further known than from captain Cook’s general chart; and none of the more distant openings, marked but not explored by that celebrated navigator, had been seen.' 35 
Hunter himself had so many preoccupations as governor that he lacked the time to pursue his own interest in surveying. ${ }^{36}$ Flinders and Bass, however, were in a position to carry out maritime surveys, and, with Hunter's support, they undertook several voyages that increased maritime knowledge of New South Wales. The first two of these excursions were made in very small boats both called Tom Thumb. The first boat was only 9-10 feet long, and had been brought to Port Jackson in the Reliance. The second Tom Thumb, built in Port Jackson under the supervision of the shipwright Daniel Paine, was less than 12 feet long. ${ }^{37}$ On the first Tom Thumb voyage, Flinders and Bass, accompanied only by a boy assistant, made a short excursion of nine days to determine whether a large river flowed into Botany Bay. They set out from Port Jackson on 26 October 1795 and followed the inland course of George's River for twenty miles beyond the limit of Hunter's prior survey of it in 1788 . They made a sketch of the river and presented it to Hunter, along with a favourable report of the land. Hunter followed up their report by visiting the vicinity twice, in November 1795 and June 1796. This led to the establishment in 1797 of Bankstown, near Sydney. ${ }^{38}$

On the second Tom Thumb voyage, Flinders, Bass and the same teenage assistant left Sydney Cove on 25 March 1796 for a voyage lasting a week to explore the region south of Botany Bay in search of an entrance to a river. Coping with stormy weather, the capsizing of the boat and a tense encounter with Aborigines, Flinders and Bass sailed as far south as modern Port Kembla, discovered a freshwater creek they named Canoe Rivulet, came across some islets, and returned to Port Jackson. ${ }^{39}$ Flinders composed charts of the area covered in this second voyage that testify to his graphical ability. They were sent back to England by Governor Hunter and published by the London commercial map seller Aaron Arrowsmith, along with a topographical plan of New South Wales prepared by Charles Grimes, the Deputy Surveyor General for the colony. This was Flinders' first published chart. ${ }^{40}$

The Tom Thumb voyages were minor excursions but they demonstrated effective cooperation between Flinders and Bass, the ability of both young naval officers to sail and control small coastal craft, and Hunter's confidence that Flinders's charts from the second voyage were sufficiently good to be enclosed with those of the professional surveyor of New South Wales for publication in London. Governor Hunter had plans for further exploration of the coastline of New South Wales. He was keen to determine whether a strait existed off the southeastern end of Australia. If proven, this would have important consequences for ships because vessels sailing through a strait to the north of Van Diemen's Land could shorten the sea route to Port Jackson, then usually undertaken around the southern coast of Van Diemen's Land, by 1,100 kilometres. ${ }^{41}$ At the time Bass Strait had not been discovered and maps showed Van Diemen's Land joined to the mainland. ${ }^{42}$

With six volunteers, Bass undertook an expedition in a whaleboat in December 1797 that sailed to the south of Port Jackson to reconnoitre previously unexplored parts of New South Wales. Flinders's naval duties in Port Jackson ruled him out from joining Bass on this voyage; otherwise he probably would have done so. ${ }^{43}$ Bass sailed around the southeastern point of Australia beyond any part of the coast seen by Cook almost thirty years earlier. In late January 1798 Bass reached Western Port, in modern Victoria, before reluctantly turning homewards as provisions were running low. Bass sketched the eastern coast of modern 
Victoria from Point Hicks, seen and named by Cook, to Western Port. ${ }^{44}$ Exposed to an open sea in the whaleboat and buffeted by gales, Bass returned to Port Jackson on 25 February after a three-month voyage. He was convinced that a wide strait separated Van Diemen's Land from New South Wales. ${ }^{45}$

Three weeks before the arrival of the whaleboat in Port Jackson, Flinders had sailed in the colonial schooner Francis to the wreck of the Sydney Cove, a merchant vessel that had run on to the beach on one of the Furneaux Islands, situated at the eastern end of Bass Strait. This was the third expedition sent out by Governor Hunter to the wreck to salvage cargo and rescue survivors. Hunter described Flinders as 'a young man well qualifyed' to carry out the task. ${ }^{46}$ Apart from referring to Flinders's navigational skills, this phrase also underscored two relevant facts. One was that Flinders had undertaken over seventy sets of observations for geographical position while in Port Jackson, and had thus demonstrated ability in nautical science. The other was that Flinders had been promoted from midshipman to acting lieutenant in June 1797 and was therefore qualified to command a small vessel. ${ }^{47}$

The voyage in the Francis had some useful outcomes. As well as rescuing survivors from the Sydney Cove, Flinders undertook a five-day expedition among surrounding islands during which he sketched and named newly discovered places and took notes on the vegetation, wildlife, and types of rock. Flinders discovered the Kent Group of Islands and began a detailed hydrographical survey of the Furneaux Group. He did not have an azimuth compass or a chronometer, but produced a chart of the area and wrote a careful description of his findings. From observation, he speculated he was situated in a strait 'dividing New South Wales from Van Diemen’s Land. ${ }^{48}$

On returning to Port Jackson, Flinders sought out Bass. The two friends agreed, from their respective recent voyages, that a strait probably existed between the southeastern mainland of Australia and Van Diemen's Land. ${ }^{49}$ Flinders drafted the first sketch to delineate Victoria's shoreline from the eastern entrance of Bass Strait to Western Port. He incorporated Bass's whaleboat material into his sketch plan, at the request of Governor Hunter, but gave due credit to Bass. ${ }^{50}$ Hunter wrote to Banks in London about the wreck of the Sydney Cove, and forwarded to the Admiralty the chart that combined the findings of Bass (in the whaleboat) and Flinders (in the Francis) in the Furneaux Islands and along the coast to Western Port. Hunter considered verification of the existence of a strait to be an important matter, as he had long believed such a strait existed. ${ }^{51}$ Action soon followed to determine the matter. Hunter fitted out the Norfolk sloop, of about twenty-five tons, and placed it under Flinders's command, with Bass and eight volunteers on board, to sail southwards from Port Jackson to determine the extent of Van Diemen's Land and whether a strait existed. This indicates Hunter's confidence in Flinders's abilities as a navigator, with Bass as an associate. The Norfolk carried provisions for twelve weeks, and Flinders was supplied with navigational equipment, including a theodolite, azimuth compass and brass sextant, but not a chronometer. ${ }^{52}$

The voyage of the Norfolk lasted from 7 October 1798 until 11 January $1799 .{ }^{53}$ In his narrative account of the voyage, Flinders noted that, at the northwestern point of Van 
Diemen's Land, 'the direction of the coast, the set of the tides and the great swell from the SW did now completely satisfy us that a very wide strait did really exist betwixt Van Diemen's Land and New South Wales, and also now that we had certainly passed it.' 54 Flinders and Bass circumnavigated Van Diemen's Land, proving for the first time that it was an island. Flinders's surveying of Van Diemen's Land corrected casual and sometimes inaccurate references to coves as bays, ports, creeks and rivers in an eye-sketch of the Derwent River area compiled by John Hayes of the Bombay Marine in 1793 - the most recent nautical sketch of the vicinity. Flinders and Bass did not have time to explore many parts of Van Diemen's Land, however, and adverse strong winds prevented them from landing on the west coast of the island. ${ }^{55}$ Flinders took great satisfaction in having his friend Bass accompany him on this voyage. ${ }^{56}$ But the two men soon parted ways. In early 1799 Bass decided to leave New South Wales to join a merchant expedition that planned to sell goods in China. Flinders and Bass never met again. ${ }^{57}$

Flinders now took the initiative in several ways to promote his interest in the navigation and surveying of Australian waters. Such a proactive approach to new discoveries was to prove essential in his making as a maritime explorer. Several months after Bass's departure from Port Jackson, he asked Governor Hunter whether he could undertake an exploration of the northern coast of New South Wales. Cook's voyage in the Endeavour had identified two large indentations in this coast. He had called these Glass-House (now Moreton) Bay and Hervey’s Bay, but only had time to chart their entrances. Governor Hunter readily agreed to Flinders's request, noting that Flinders was 'fond of being so employed \& is in that way very capable.' Hunter wanted to find out whether rivers led into the interior of New South Wales. He was particularly interested in the exploration of Hervey's Bay, which he thought 'from the largeness of the opening may shew us a large \& extensive sea within, or perhaps a navigable river which may lead us some distance into the interior of the Country., 58

Flinders was again assigned the Norfolk for the expedition, and the voyage occurred between 8 July and 21 August 1799. Flinders wanted to find a major river into the continent's centre partly to improve geographical knowledge but also to prove his own credentials as a maritime explorer who could amplify and extend Cook's findings. ${ }^{59}$ Flinders wrote an account of this voyage that consciously followed the earlier writings of Cook, the only previous navigator to visit this coast. Flinders identified some differences between his own observations and Cook's recording of coastal features on his chart. He also suggested that what Cook termed the Solitary Isles might well have been called the Miserable Isles, judging from their dreary appearance. Flinders provided descriptions of headlands and of Shoal Bay; he clarified Cook's account in his journal of this coastline; and he hoped to be credited for his detailed description of the voyage. ${ }^{60}$ Flinders found that neither Hervey's Bay nor Glasshouse Bay had suitable harbours to shelter a ship against winds. He was disappointed by the results of his expedition in the Norfolk, especially finding there was no river of importance intersecting the east coast between $24^{\circ}$ and $39^{\circ}$ of latitude south, in other words between Breaksea Spit and Wilson's Promontory. ${ }^{61}$

Hunter and Flinders both acted independently to inform Sir Joseph Banks and the Admiralty of the discovery of Bass Strait, the circumnavigation of Van Diemen's Land and 
the voyage in the Norfolk to northern New South Wales. In June 1799 Hunter reported the voyage around Van Diemen's Land to Banks and the Admiralty, noting that Flinders's and Bass's survey had been made 'under many inconveniences, but is yet so correct as to be highly satisfactory.' He hoped this discovery would provide impetus for further exploration of Australia. ${ }^{62}$ On 15 August 1799 Hunter dispatched to London Flinders's chart of Bass Strait. ${ }^{63}$ Some months later he wrote to Banks to praise Flinders' work as a maritime surveyor, and hoped that the British government could provide him with a qualified person to continue the examination of Australia's coastline in a suitable vessel. ${ }^{64}$

Flinders later contacted Banks to seek permission from the Admiralty to publish and engrave the charts. ${ }^{65}$ The Admiralty selected Aaron Arrowsmith, who knew Banks well, to undertake the task. On 16 June 1800 Arrowsmith published A Chart of Bass's Strait between New South Wales and Van Diemen's Land, Explored by Matthw. Flinders $2^{\text {nd }}$ Lieut. of his Majesty's Ship Reliance, by order of His Excellency Governor Hunter 1798-9. The chart carefully followed Flinders's topography, nomenclature and notations. ${ }^{66}$ Arrowsmith also published a Chart of Part of the Coast of New South Wales, from Ram Head to Northumberland Isles, by M.Flinders, $2^{\text {nd }}$ lieut. of H.M.S. Reliance, 1800. This was the most extensive and accurate chart of coastal Australia ever published. Flinders liaised closely with Arrowsmith about the details represented on the chart. ${ }^{67}$ Arrowsmith published two further charts by Flinders on 20 February 1801, depicting on one Port Dalrymple, in northern Van Diemen's Land, the southernmost of the Furneaux Islands and Western Port, and on the other part of the New South Wales coast from Ram's Head to the Northumberland Isles. ${ }^{68}$

By the beginning of 1800, Flinders was nearing the end of his stint in New South Wales. He knew that the British government was considering further examination of the Australian coast, and he hoped his achievements in exploring New South Wales and Van Diemen's Land might be rewarded by his being given command of an expedition. ${ }^{69}$ This had already been proposed, in fact, by very influential people who knew about his achievements in maritime exploration in New South Wales. Banks had briefly met Flinders twice in 1793 when matters connected with second breadfruit voyage needed to be settled. ${ }^{70}$ In May 1798 Banks had already recommended that Flinders - 'A Countryman of mine, a Man of activity \& information, who is already there' - should be entrusted with the command of a vessel to continue exploring New South Wales. ${ }^{71}$ Philip Gidley King, a former naval captain about to take over from Hunter as Governor of New South Wales, also suggested to Banks in March 1799 that Flinders would be a suitable commander for a surveying voyage in Australian waters. ${ }^{72}$ Flinders knew about these recommendations. 'We are now given to understand,' he wrote to a friend on 17 January 1800, 'that it is the contemplation of Government to send out one or two vessels to carry on the examination of this still immense ('still immense' even when Van Diemen's Land was found to be separated) Island, the command of which, report has given to me, although the material discoveries already made must be unknown to them., ${ }^{73}$

When he wrote this letter, Flinders was correct in thinking that a British voyage of discovery to Australia was imminent, but he did not know that the Lady Nelson, under the command of James Grant, a young Scots naval lieutenant, had just joined the East India fleet at Portsmouth on a voyage to survey the coastline of New South Wales and to probe for any 
waterway that might divide the mainland or allow access to the interior. Banks wrote the instructions for this expedition, which envisaged that Grant would hand over the command of the Lady Nelson to Flinders at Port Jackson. ${ }^{74}$ This expedition arose after Banks and Hunter had corresponded about the need for further exploration of New South Wales, both along the coast and inland, so that the small British bridgehead at Port Jackson might expand into a broader territory to benefit the mother country. ${ }^{75}$ While the Lady Nelson was sailing out to Port Jackson, Flinders had come to the end of his service in New South Wales. He left Port Jackson in the Reliance on 3 March 1800 and arrived at Plymouth on 27 August, having been away from home for five-and-a-half years. ${ }^{76}$

Flinders must have gleaned information about the Lady Nelson's voyage soon after he returned home. He would undoubtedly have been disappointed to miss the chance of gaining her command at Port Jackson. Rather than responding to the news as a lost opportunity, however, Flinders seized the initiative. Only eleven days after returning to England, he wrote a bold letter on 6 September 1800 to Banks requesting support for a major voyage of maritime discovery to Australia. This was an unusual course to follow: it was more common, as with Cook, for the Admiralty to agree to support a voyage of discovery and then to find an appropriate commander. But the decision to approach Banks rather than the Admiralty demonstrated what Ernest Scott thought was Flinders's most salient characteristic: his initiative. ${ }^{77}$ Flinders knew Banks was the single most important person in London acting as patron and conduit for voyages of exploration. At the turn of the nineteenth century, he was virtually the 'managing director' of all British proposals concerning Australia. ${ }^{78}$ Banks's authority rested not just on his on scientific ability concerning botany but on being in a prime position to assist others and influence governments. ${ }^{79}$ Without Banks's support, Flinders's proposal for a voyage of discovery stood little chance of acceptance. ${ }^{80}$

Flinders's letter of 6 September 1800 - probably the most important one he ever wrote - referred to his charts of Van Diemen's Land and Bass Strait and discussed his work in surveying the coast of New South Wales. It emphasised the importance of a further, more ambitious voyage to promote British imperial interests and to extend knowledge of Australian geography and natural history, and provided a knowledgeable account of how exploration of New South Wales and New Holland should be completed. Flinders noted that 'a very great part of that still extensive country remains either totally unknown, or has been partially examined at a time when navigation was much less advanced than at present.' Flinders tapped Banks's interest in botany by noting that the voyage to Australia 'should examine into the natural productions of this wonderful country. ${ }^{81}$ The letter also referred to a conjecture that 'a still larger than Bass' Strait dismembers New Holland.' 82 This was a much-discussed idea at the time, stemming from distrust about the accuracy of maps depicting Australia. ${ }^{83}$ Banks willingly supported Flinders's proposal for a voyage of discovery and became the main patron of the Investigator expedition. ${ }^{84}$ By mid-November 1800 Banks agreed to discuss Flinders's plans for such a voyage. Over the next two months Banks coordinated most of the arrangements necessary to find a ship and prepare for the Australian circumnavigation. This led to Flinders being appointed commander of the Investigator. ${ }^{85}$ 
Flinders's letter to Banks of 6 September was the immediate stimulus for serious attention to be paid to a voyage of Australian circumnavigation, which was to establish Flinders's reputation as a maritime explorer. Its timing was astutely judged by Flinders, as it was written fairly soon after he had returned from an extensive stay in New South Wales towards the end of which he had found out that Banks and the Admiralty were already thinking of a major voyage of discovery to Australia and that that he might be offered the expedition's command. Flinders had correctly judged that seizing the opportunity to contact Banks was a proactive way of presenting his credentials and experience for the intended voyage. ${ }^{86}$ It was an audacious step because Flinders was a young naval lieutenant and Banks was an eminent man - a long-term President of the Royal Society and the central figure in the promotion and organisation of voyages to the Pacific for over thirty years. Banks had close connections with the government departments that needed to be contacted about a major voyage of exploration and he personally knew the leading political and administrative figures that had to be consulted. ${ }^{87}$

Besides these points, however, it is clear that the making of Flinders as a maritime explorer had being forged through his successive nautical achievements during the 1790s. He had absorbed the finer points of surveying and chart making through sailing with Bligh in the Providence; and from Bligh, as well as through the study of books and charts, he had learned of Cook's contributions to nautical discovery. The second breadfruit voyage had also given the young Flinders experience of long oceanic voyages. But it was his sojourn in New South Wales between 1795 and 1800 that was crucial in the making of Flinders as a maritime explorer of Australia. He gained the confidence of Governor Hunter, himself a surveyor, and through Hunter's approbation he was favourably mentioned to Banks. Flinders used his initiative on several voyages in Australian waters, leading to his joint discovery of Bass Strait with his friend Bass and the first circumnavigation of Van Diemen's Land, which proved it was an island. Flinders publicised his own findings by sending back details of his charts to London and liaising with the eminent cartographer Arrowsmith over publication of charts depicting his new discoveries. When Bass left Port Jackson in 1800, Flinders was the only person there with the experience to command a more detailed, complex expedition to acquire new knowledge about Australia. Flinders's skills as a cartographer and hydrographer were to undergo further refinement on the Investigator expedition; but before he set out on that voyage, he had already gained good enough first-hand experience of the different elements of nautical science and of Australia's coastal geography to mark him out as suitable to take command of the first circumnavigation of Australia. ${ }^{88}$

\section{Acknowledgment}

This paper was prepared for a panel entitled 'Before the Pacific: Critical Factors in the Making of an Explorer,' presented at the 7th IMEHA International Congress of Maritime History, Murdoch University, Perth, June 2016.

\section{Funding}


Research for this article was supported by an Australian Bicentennial Fellowship, Menzies Centre for Australian Studies, King's College, London.

\footnotetext{
${ }^{1}$ Scott, The Life of Matthew Flinders, 14.

${ }^{2}$ These achievements are discussed in Scott, The Life of Matthew Flinders and Estensen, The Life of Matthew Flinders.

${ }^{3}$ State Library of Victoria, Melbourne, 'A Brief memoir of Captain Matthew Flinders. R. N.,' p. 2, J. J. Shillinglaw Papers, box 81, 81/3(d). Admiral W. H Smyth was the author of this memoir, written c.1845: see National Maritime Museum (NMM), Greenwich, Flinders Papers, FLI/105.

${ }^{4}$ Scott, The Life of Matthew Flinders, pp. 11-14.

${ }^{5}$ Pasley’s recommendation of Flinders to Bligh is referred to in Beardsley and Bennett, eds., 'Gratefull to Providence', II, 94.

${ }^{6}$ Salmond, Bligh, 215-25.

${ }^{7}$ Ibid., 111-12, 115-19, 331-2, 334, 336.

${ }^{8}$ Beaglehole, ed., The Endeavour Journal of Joseph Banks.

${ }^{9}$ Salmond, Bligh, 40-2.

${ }^{10}$ Gall, ed., In Bligh's Hand, 85.

11 The National Archives, Kew (TNA), ADM 55/97, Flinders, Log in the Providence, entry for 26 March 1792, f. 24. For commentary on this logbook, see Darby, 'Bligh’s Disciple,' 401-11.

12 TNA, ADM 55/97, Flinders, Log in the Providence, f. 38. The information presented here drew upon impressions gathered on Cook's three visits to Tahiti, as discussed in Salmond, Aphrodite's Island, 141-202.

${ }^{13}$ TNA, ADM 55/97, Flinders, Log in the Providence, entry for 17 September 1792, f. 100.

${ }^{14}$ Morgan, ed., Australia Circumnavigated, II, 482.

15 Ibid., II, 482.

${ }^{16}$ NMM, Papers relating to Flinders’ career: Memoir of official services, Flinders Papers, $\mathrm{FLI} / 5$.

${ }^{17}$ Salmond, Bligh, 54-5. The extent of Bligh's debt to Cook is open to discussion: see Beaglehole, The Life of Captain Cook, 498. Bligh's surveying is discussed in David, 'The Surveyors of the Bounty.'

${ }^{18}$ Ingleton, Matthew Flinders, 15-16.

${ }^{19}$ Gascoigne, Captain Cook, 44.

20 TNA, ADM 55/97, Flinders, Log in the Providence, ff. 2-6.

${ }^{21}$ Estensen, The Life of Matthew Flinders, 20. The manuscript chart is at NMM, Flinders Papers, FLI/15/1.

22 David, 'The Surveyors of the Bounty,' 16c.

${ }^{23}$ Salmond, Bligh, 423-4. Bligh's chart surveying Torres Strait is found in the Mitchell Library, Sydney (ML), Safe/F79/5.

${ }^{24}$ Flinders, A Voyage to Terra Australis, I, xxi-xxiii, xxv-xxvi, xxix.

${ }^{25}$ Wood, The Discovery of Australia, 341.

${ }^{26}$ NMM, Matthew Flinders' certificate for lieutenancy, January 1797, Flinders Papers, 60/017, FLI/5.

${ }^{27}$ Bowden, George Bass, 27.

${ }^{28}$ Estensen, The Life of Matthew Flinders, 39.

${ }^{29}$ Flinders, A Voyage to Terra Australis, I, xcvi.
} 
${ }^{30}$ May, 'The "Reliance” Log Books of Matthew Flinders,' 268-9.

${ }^{31}$ Estensen, The Life of George Bass.

${ }^{32}$ Flinders, A Voyage to Terra Australis, I, xcvii.

${ }^{33}$ Ingleton, 'Flinders as Cartographer,' 64.

${ }^{34}$ Estensen, The Life of Matthew Flinders, 42-5; Hunter, An Historical Journal of the Transactions at Port Jackson and Norfolk Island, 42; Perry, 'Charts and Views,' 72-8.

${ }^{35}$ Flinders, A Voyage to Terra Australis, I, xcvi-xcvii.

${ }^{36}$ Hunter to Banks, 1 August 1797, in Chambers, ed., The Indian and Pacific Correspondence, IV, 459.

${ }^{37}$ Estensen, The Life of Matthew Flinders, 52-3; R.J.B. Knight and Alan Frost, eds., The Journal of Daniel Paine 1794-1797, together with Documents illustrating the Beginning of Government Boat-building and Timber-gathering in New South Wales, 1795-1805

(Greenwich, 1983), 39.

${ }^{38}$ Sprod, ed., Van Diemen's Land Revealed, 7.

${ }^{39}$ Bowden, ed., Matthew Flinders' Narrative of Tom Thumb's Cruise to Canoe Rivulet, 4-6, 9-10, 12-13, 18-19.

${ }^{40}$ Estensen, The Life of Matthew Flinders, 60-1. Arrowsmith's publication was entitled $\underline{A}$ Topographical Plan of the Settlement of New South Wales, Including port Jackson, botany Bay and Broken Bay. Surveyed by Messrs Grimes and Flinders - Communicated by Lt. Col. Paterson of the New South Wales Corps (London, 1799).

${ }^{41}$ Estensen, The Life of George Bass, 115-16.

${ }^{42}$ Tooley, The Mapping of Australia, xiii.

${ }^{43}$ Scott, The Life of Matthew Flinders, 68-9.

${ }^{44}$ Scott, 'English and French Navigators on the Victorian Coast,' 158; Cole, 'George Bass and the Whaleboat Voyage,' 77-97; Estensen, The Life of George Bass, 75-95.

${ }^{45}$ Flinders, A Voyage to Terra Australis, I, cxiii, cxix.

${ }^{46}$ Hunter to the Duke of Portland, 1 March 1798, in Watson, ed., Historical Records of Australia, II, 134.

${ }^{47}$ Ingleton, 'Flinders as Cartographer,' 64.

${ }^{48}$ Flinders, 'Narrative of an expedition to Furneauxs Islands,' 12-13; Aurosseau, 'Flinders' Voyage in the Francis,' 111-13.

${ }^{49}$ Estensen, The Life of Matthew Flinders, 70-1.

${ }^{50}$ United Kingdom Hydrographic Office, Ministry of Defence Archives, Taunton, Matthew Flinders, 'Sketch of the Parts between Van Diemen's Land and New South Wales. Seen in the Francis schooner 1798. By M. Flinders 2 Lieut. of H.M. Ship Reliance. The Part of New South Wales was coasted by Mr. Bass, Surgeon of the Reliance in a whale boat \& where not seen in the Francis is taken from him,' chart y65, shelf X. Bass reported the sketch in a letter to Lt.-Col. Paterson, 20 August 1797, in Bladen, ed., Historical Records of New South Wales, III, 289. The sketch is reproduced in Cole and Cole, Mr Bass’s Western Port, 63, 65.

${ }^{51}$ Hunter to Evan Nepean, 3 September 1798, in Watson, ed., Historical Records of Australia, II, 221; Hunter to Banks, 12 March, 25 July 1798, in Chambers, ed., The Indian and Pacific Correspondence, IV, 489-93.

${ }^{52}$ Estensen, The Life of Matthew Flinders, 72-3; Flinders, A Voyage to Terra Australis I, cxxxviii.

${ }^{53}$ Annotated excerpts from Flinders' and Bass's notes on the voyage appear in Macknight, ed., Low Head to Launceston, 1-53.

${ }^{54}$ Flinders, 'Narrative of the expedition of the colonial sloop Norfolk,' 48.

${ }^{55}$ Flinders, Observations on the Coasts of Van Diemen's Land, 2, 5.

${ }^{56}$ Flinders, 'Narrative of the expedition of the colonial sloop Norfolk,' 59-62. 
${ }^{57}$ Roe, ed., The Journal and Letters of Captain Charles Bishop, xliii-xliv.

${ }^{58}$ Estensen, The Life of Matthew Flinders, 91-2; Hunter to Banks, 1 June 1799, in Chambers, ed., The Indian and Pacific Correspondence, V, 85-8 (both quotations).

${ }^{59}$ Flinders, A Voyage to Terra Australis, I, cxciii. A descriptive account of Flinders' voyage to northern New South Wales in August 1799 is provided in Collins, ed. Fletcher, $\underline{\text { An }}$ Account of the English Colony in New South Wales, I, 161-88.

${ }^{60}$ ML, Matthew Flinders, Journal in the Norfolk sloop, 1799, MS C211/2; Smith, 'Matthew Flinders and the North Coast of New South Wales,' 163-8.

${ }^{61}$ NMM, Matthew Flinders, Journal kept on board the Reliance (1798-9), entry for 21 August 1799, ADM/L/R/79B; Flinders, A Voyage to Terra Australis, I, ccii. There are, in fact, several rivers along this coast, but Flinders probably missed them because of the absence of estuaries: see Perry, 'Seasons for Exploration,' 54.

${ }^{62}$ Hunter to Banks, 1 June 1799, in Chambers, ed., The Indian and Pacific Correspondence, $\mathrm{V}, 85-8$.

${ }^{63}$ Hunter to Nepean, 15 August 1799, in Watson, ed., Historical Records of Australia, II, 381.

${ }^{64}$ Hunter to Banks, 20 February 1800, in Chambers, ed., The Indian and Pacific

Correspondence, V, 159-60.

${ }^{65}$ Lincolnshire Archives, Flinders to Dr Matthew Flinders, 19 November 1800, Flinders Correspondence, $3 / 2$.

${ }^{66}$ Ingleton, Matthew Flinders, 52. Arrowsmith's chart had a few errors which Flinders corrected, leading to publication of a revised version of the chart on 20 February 1801: see Morgan, Matthew Flinders, 42.

${ }^{67}$ Flinders provided material from his own chart to aid Arrowsmith: that chart is in TNA, ADM 352/489, Original Surveys: Australia, east coast: Queensland; Port Stephens to Northumberland islands.

68 Tooley, 'The Printed Maps of New South Wales,' 10-11. For commentary on the details included in these charts, see Gooch, 'Puzzling over the Early Flinders Charts,' 5-22.

${ }^{69}$ NMM, Flinders to Pultney Malcolm, 17 January 1800, Flinders Papers, FLI/8a.

${ }^{70}$ James Wiles to Banks, 16 March 1793, and Flinders to Banks, 21 October 1793, in Chambers, ed., The Indian and Pacific Correspondence, IV, 96, 158.

${ }^{71}$ Banks to John King, 15 May 1798, ibid., IV, 502. The first part of the quotation reflects the fact that Banks and Flinders had strong attachments to Lincolnshire - Banks by inheritance and Flinders by birth.

${ }^{72}$ Philip Gidley King to Banks, 20 March 1799, in Chambers, ed., The Indian and Pacific Correspondence, V, 60.

${ }_{73}^{7 M M}$, Flinders to Pulteney Malcolm, 17 January 1800, Flinders Papers, FLI/8a.

74 'Notes regarding the Lady Nelson' [1800] in Chambers, ed., The Indian and Pacific Correspondence, V, 142-6. Grant was involved in local maritime exploration from Port Jackson during 1801 but then returned to England. See McMartin, 'Grant, James' in Pike, ed., Australian Dictionary of Biography, I, 468-9.

${ }^{75}$ Mackay, 'In the Shadow of Cook,' 105-6.

${ }^{76}$ Estensen, The Life of Matthew Flinders, 110-11.

77 Scott, 'The Flinders Centenary,' 101.

${ }^{78}$ Bertie, 'Matthew Flinders,' 303.

${ }^{79}$ Withers, Placing the Enlightenment, 125.

${ }^{80}$ Rigby, '”The whole of the surveying department rested on me”,' 263.

${ }^{81}$ Flinders to Banks, 6 September 1800 in Brunton, ed., Matthew Flinders, 51.

${ }^{82}$ Ibid.

${ }^{83}$ Ritchie, The Admiralty Chart, 81. 
${ }^{84}$ Morgan, 'Sir Joseph Banks as patron of the Investigator expedition,' 235-64.

${ }^{85}$ Banks to Flinders, 16 November 1800, in Chambers, ed., The Indian and Pacific Correspondence, V, 217.

${ }^{86}$ For an astute analysis of the letter, see Perry, 'Matthew Flinders - The Man,' 53-7.

${ }^{87}$ Williams, '”The common Center of We Discoverers”,' 177-91.

${ }^{88}$ West-Sooby, 'Baudin, Flinders and the Scientific Voyage,' 181.

\section{References}

Arrowsmith, Aaron, A Topographical Plan of the Settlement of New South Wales, Including port Jackson, botany Bay and Broken Bay. Surveyed by Messrs Grimes and Flinders Communicated by Lt. Col. Paterson of the New South Wales Corps (London, 1799).

Aurosseau, M., 'Flinders’ Voyage in the Francis, 1798,' The Geographical Journal, CXI (1948), 111-13.

Beaglehole, J. C., ed., The Endeavour Journal of Joseph Banks, 1768-1771, 2 vols. (Sydney: Angus \& Robertson, 1962).

Beaglehole, J. C., The Life of Captain Cook (Stanford: Stanford University Press, 1974).

Beardsley, Martyn and Bennett, Nicholas, eds., 'Gratefull to Providence”: The Diary and Accounts of Matthew Flinders, Surgeon, Apothecary and Man-Midwife, 1775-1802. Volume 2. 1775-1802, Lincoln Record Society, 97 (Lincoln: Lincoln Record Society, 2009).

Bertie, Charles H., 'Matthew Flinders, Australia’s Navigator,' Journal and Proceedings of the Australian Historical Society, 3 part VII (1915-17), 295-325.

Bladen, F. M., ed., Historical Records of New South Wales, 7 vols. (Sydney: Government Printer, 1892-1901).

Bowden, Keith Macrae, George Bass 1771-1803: His Discoveries, Romantic Life and Tragic Disappearance (Melbourne: Melbourne University Press, 1952).

Bowden, Keith, ed., Matthew Flinders’ Narrative of Tom Thumb’s Cruise to Canoe Rivulet (Brighton, VIC: South Eastern Historical Association, 1985).

Brunton, Paul, ed., Matthew Flinders: Personal Letters from an Extraordinary Life (Sydney; Hordern House in association with the State Library of New South Wales, 2002).

Chambers, Neil, ed., The Indian and Pacific Correspondence of Sir Joseph Banks, 1768-1820. Volume 4: Letters 1792-1798 (London: Pickering \& Chatto, 2011).

Chambers, Neil, ed., The Indian and Pacific Correspondence of Sir Joseph Banks, 1768-1820. Volume 5: Letters 1798-1801 (London: Pickering \& Chatto, 2012). 
Cole, Harry and Valda, Mr Bass's Western Port. The Whaleboat Voyage (Hastings, VIC: Hastings-Western Port Historical Society in association with the South Eastern Historical Association, 1997).

Cole, Valda, 'George Bass and the Whaleboat Voyage,' Victorian Historical Journal, 69 no. 2 (1998), 77-97.

Collins, David, ed. B. H. Fletcher, An Account of the English Colony in New South Wales. With Remarks on the Dispositions, Customs, Manners etc. of the Native Inhabitants of that Country, 2 vols. (Sydney: Reed in association with the Royal Historical Society, 1975).

Darby, Madge, ‘Bligh’s Disciple: Matthew Flinders’s Journals of HMS Providence, 17911793,' The Mariner's Mirror, 86 no. 4 (2000), 401-11.

David, Andrew C. F., 'The Surveyors of the Bounty: A Preliminary Study of the Hydrographic Surveys of William Bligh, Thomas Hayward and Peter Heywood and the charts published from them' (unpublished typescript, Royal Navy Hydrographic Department, Ministry of Defence Archives, Taunton, 1982).

Estensen, Miriam, The Life of Matthew Flinders (Sydney: Allen \& Unwin, 2002).

Estensen, Miriam, The Life of George Bass, Surgeon and Sailor of the Enlightenment (Crows Nest, NSW: Allen \& Unwin, 2005).

Flinders, Matthew, Observations on the Coasts of Van Diemen's Land on Bass's Strait and its Islands, and on part of the Coasts of New South Wales; intended to accompany the Charts of the late Discoveries in those Countries (London: John Nichols, 1801).

Flinders, Matthew, A Voyage to Terra Australis; undertaken for the purpose of completing the discovery of that vast country, and prosecuted in the years 1801, 1802, and 1803, in his Majesty's Ship the Investigator, and subsequently in the Armed Vessel Porpoise and Cumberland Schooner, With an account of the shipwreck of the Porpoise, arrival of the Cumberland at Mauritius, and imprisonment of the Commander during six and a hal years in that island, 2 vols. (London: G. \& W. Nicol, 1814).

Flinders, Matthew, 'Narrative of an expedition to Furneauxs Islands on the coast of New South Wales, in the Port-Jackson colonial schooner Francis. By Matthew Flinders 2 Lieut. of H. M. Ship Reliance March 1798,’ La Trobe Library Journal, 13 (1974), 4-13.

Flinders, Matthew, 'Narrative of the expedition of the colonial sloop Norfolk' in Sprod, Dan, ed., Van Diemen's Land Revealed: Flinders and Bass and their Circumnavigation of the Island in the Colonial Sloop Norfolk 1798-1799 (Hobart: Blubber Head Press, 2009).

Gall, Jennifer, ed., In Bligh's Hand: Surviving the Mutiny on the Bounty (Canberra: National Library of Australia, 2011).

Gascoigne, John, Captain Cook: Voyager between Worlds (London: Continuum, 2007). 
Gooch, Ruth, 'Puzzling over the Early Flinders Charts,' Victorian Historical Journal, 78 no. 1 (2007), 5-22.

Hunter, John, An Historical Journal of the Transactions at Port Jackson and Norfolk Island (London: John Stockdale, 1795).

Ingleton, Geoffrey C., 'Flinders as Cartographer' in R. W. Russell, ed., Matthew Flinders The Ifs of History (Bedford Park, SA: University Relations Unit, Flinders University, 1979).

Ingleton, Geoffrey C., Matthew Flinders: Navigator and Chartmaker (Guildford: Genesis Publications in association with Hedley Australia, 1986).

Knight, R.J.B. and Frost, Alan, eds., The Journal of Daniel Paine 1794-1797, together with Documents illustrating the Beginning of Government Boat-building and Timber-gathering in New South Wales, 1795-1805 (Greenwich: National Maritime Museum, 1983).

Mackay, David, 'In the Shadow of Cook: The Ambition of Matthew Flinders' in John Hardy and Alan Frost, eds., European Voyaging towards Australia (Canberra, 1990).

Macknight, C. C., ed., Low Head to Launceston: The Earliest Reports of Port Dalrymple and the Tamar (Launceston: Historical Survey of Northern Tasmania, 1998).

McMartin, Arthur, 'Grant, James (1772-1833’ in Douglas Pike, ed., Australian Dictionary of Biography (Melbourne, 1966), I, 468-9.

May, W. E., 'The "Reliance” Log Books of Matthew Flinders,' Journal of the Royal Australian Historical Society, XXXIX (1953), 267-74.

Morgan, Kenneth, 'Sir Joseph Banks as patron of the Investigator expedition: natural history, geographical knowledge and Australian exploration,' International Journal of Maritime History, 26 no. 2 (2014), 235-64.

Morgan, Kenneth, ed., Australia Circumnavigated: The Journals of Matthew Flinders in HMS Investigator, 1801-1803, 2 vols., Hakluyt Society, third series, 28-9 (London: Ashgate, 2015).

Morgan, Kenneth, Matthew Flinders, Maritime Explorer of Australia (London, 2016).

Perry, T. M., 'Seasons for Exploration: the Second Daniel Brock Memorial Lecture, 1975,' Proceedings of the Royal Geographical Society Australasia, South Australian Branch, 76 (1975), 51-8.

Perry, T. M., 'Matthew Flinders - The Man' in R. W. Russell, ed., Matthew Flinders - The Ifs of History (Bedford Park, SA: University Relations Unit, Flinders University, 1979).

Perry, T. M., 'Charts and Views' in Bernard Smith and Alwyne Wheeler, eds., The Art of the First Fleet and other Early Australian Drawings (New Haven: Yale University Press, 1988).

Rigby, Nigel, '”The whole of the surveying department rested on me”: Matthew Flinders, Hydrography and the Navy’ in Marc Serge Rivière and Kumari Issur, ed., Baudin-Flinders 
dans l'océan indien: voyages, découvertes, rencontre: travels, discoveries, encounter[s] (Paris, 2006).

Ritchie, G. S., The Admiralty Chart: British Naval Hydrography in the Nineteenth Century, new edn. (Bishop Auckland: Pentland Press, 1995).

Roe, Michael, ed., The Journal and Letters of Captain Charles Bishop on the North-West Coast of America, in the Pacific and in New South Wales 1794-1799, Hakluyt Society, series II, CXXXI (Cambridge: Cambridge University Press, 1967).

Salmond, Anne, Aphrodite's Island: The European Discovery of Tahiti (Berkeley and Los Angeles: University of California Press, 2010).

Salmond, Anne, Bligh: William Bligh in the South Seas (Berkeley and Los Angeles: University of California Press, 2011).

Scott, Ernest, 'The Flinders Centenary,' The Lone Hand, new series, II no. 8 (1 July 1914), 101-3.

Scott, Ernest, 'English and French Navigators on the Victorian Coast,' Victorian Historical Magazine, II no. 4 (1912), 145-76.

Scott, Ernest, The Life of Matthew Flinders (Sydney: Angus \& Robertson, 1914).

Smith, Robert James, 'Matthew Flinders and the North Coast of New South Wales, 1799,' Journal of the Royal Australian Historical Society, 85 no. 2 (1999), 163-8.

Sprod, Dan, ed., Van Diemen's Land Revealed: Flinders and Bass and their Circumnavigation of the Island in the Colonial Sloop Norfolk 1798-1799 (Hobart: Blubber Head Press, 2009).

Tooley, R. V., 'The Printed Maps of New South Wales, 1773-1873,' Map Collectors' Circle no. 44 (1968).

Tooley, R. V., The Mapping of Australia (London: Holland Press, 1979).

Watson, Frederick, ed., Historical Records of Australia, 33 vols. (Sydney: Government Printer, 1914-25).

West-Sooby, John, 'Baudin, Flinders and the Scientific Voyage' in Marc Serge Rivière and Kumari R. Issur, eds., Baudin-Flinders dans l’Océan Indien: Voyages, Découvertes, Rencontre: Voyages, Discoveries, Encounter (Paris: L'Harmattan, 2006).

Williams, Glyndwr, '”The common Center of We Discoverers”: Sir Joseph Banks, Exploration and Empire in the Late Eighteenth Century’ in R.E.R. Banks, B. Elliott, J. G. Hawkes, D. King-Hale and G. L. Lucas, eds., Sir Joseph Banks: A Global Perspective (Kew: The Royal Botanic Gardens, 1994). 
Withers, Charles W. J., Placing the Enlightenment: Thinking Geographically about the Age of Reason (Chicago, 2007).

Wood, G. Arnold, ed. J. C. Beaglehole, The Discovery of Australia, rev. edn. (Melbourne: Macmillan of Australia, 1969). 